\title{
THE IMPACT OF THE MACROECONOMY ON HEALTH INSURANCE COVERAGE: EVIDENCE FROM THE GREAT RECESSION
}

\author{
John Cawley \\ Asako S. Moriya \\ Kosali I. Simon \\ Working Paper 17600 \\ http://www.nber.org/papers/w17600 \\ NATIONAL BUREAU OF ECONOMIC RESEARCH \\ 1050 Massachusetts Avenue \\ Cambridge, MA 02138 \\ November 2011
}

The authors declare no financial relationships that could represent a conflict of interest. The views expressed herein are those of the authors and do not necessarily reflect the views of the National Bureau of Economic Research.

NBER working papers are circulated for discussion and comment purposes. They have not been peerreviewed or been subject to the review by the NBER Board of Directors that accompanies official NBER publications.

(C) 2011 by John Cawley, Asako S. Moriya, and Kosali I. Simon. All rights reserved. Short sections of text, not to exceed two paragraphs, may be quoted without explicit permission provided that full credit, including $(\mathbb{C}$ notice, is given to the source. 
The Impact of the Macroeconomy on Health Insurance Coverage: Evidence from the Great Recession

John Cawley, Asako S. Moriya, and Kosali I. Simon

NBER Working Paper No. 17600

November 2011, Revised October 2013

JEL No. E32,I13,J32,J6

\section{ABSTRACT}

This paper investigates the impact of the macroeconomy on the health insurance coverage of Americans using panel data from the Survey of Income and Program Participation (SIPP) for 2004-2010, a period that includes the Great Recession of 2007-09. We find that a one percentage point increase in the state unemployment rate is associated with a 1.67 percentage point $(2.12 \%)$ reduction in the probability that men have health insurance; this effect is strongest among college-educated, white, and older (50-64 year old) men. For women and children, health insurance coverage is not significantly correlated with the unemployment rate, which may be the result of public health insurance acting as a social safety net. Compared to the previous recession, the health insurance coverage of men is more sensitive to the unemployment rate, which may be due to the nature of the Great Recession.

John Cawley

3M24 MVR Hall

Department of Policy Analysis and Management

and Department of Economics

Cornell University

Ithaca, NY 14853

and NBER

jhc38@cornell.edu
एس山KKosali I. Simon

एسm $\mathrm{W}$ School of Public and Environmental Affairs

Indiana University

Rm 359

1315 East Tenth Street

Bloomington, IN 47405-1701

and NBER

simonkos@indiana.edu

Asako S. Moriya

School of Public and Environmental Affairs

Indiana University

1315 E. Tenth Street Room 441

Bloomington, IN 47405

asako.moriya@gmail.com 


\section{Introduction}

The number of Americans lacking health insurance has long been a concern of policymakers. The uninsured tend to receive less medical care and thus be in worse health than the insured (Finkelstein et al., 2012, Card et al., 2009; Doyle, 2005; also see the reviews in McWilliams, 2009 and Freeman et al., 2008). Moreover, uninsured individuals are at risk of severe financial loss, including bankruptcy, in the event of illness (Gross and Notowidigdo, 2011; Himmelstein et al., 2009). Concerns about the adverse consequences of uninsurance led the U.S. Congress, in 2010, to pass the Patient Protection and Affordable Care Act (PPACA), which expands eligibility for public health insurance and establishes a variety of incentives for employers to offer health insurance and for employees to take up such plans.

The high and rising cost of providing public health insurance is a budgetary concern for the federal and state governments (Chernew et al., 2009). The budgetary strain rises during macroeconomic downturns, as increasing numbers of people are covered by Medicaid and the Children's Health Insurance Program (henceforth referred to collectively as Medicaid). Between 2005 and 2011, the Medicaid caseload rose by 12.6 million or 33.1\% (DeNavas-Walt et al., 2012, Table C-2); it is not clear to what extent this was due to the recession or longer-run trends.

The economic expansion that began in November 2001 ended in December 2007, and the ensuing recession lasted until June 2009 (NBER Business Cycle Dating Committee, 2011). This recession, which lasted 18 months, was the longest in the United States since 1933. It was also the most severe recession in the U.S. since World War II, as employment fell by $6.3 \%$ and output fell by 5.1\% (Federal Reserve Bank of Minneapolis, 2011). 
This paper estimates the impact of the macroeconomy on the number of Americans with health insurance coverage, both overall and by source of coverage. By focusing on the recession of 2007-09, this paper extends and builds on previous work that has examined the impact of the macroeconomy on uninsurance during the previous (2001) recession (Cawley and Simon, 2005). It also contributes to the larger economics literature on the consequences of the 2007-09 recession, which has been dubbed the Great Recession (e.g. Farber, 2011; Hurd and Rohwedder, 2010).

Our primary measure of the macroeconomy is the state unemployment rate. This is the most common measure used in the substantial literature on the macroeconomy and health (see, e.g., the review in Ruhm, 2006). Moreover, in our previous work (Cawley and Simon, 2005) we found that the state unemployment rate was far more predictive of insurance status than other measures such as the gross state product or indicator variables for recession. As an extension, we examine how results differ when we use the employment rate rather than the unemployment rate.

While there is a large literature on the direct effect of the macroeconomy on health (e.g. Ruhm, 2003; Ruhm, 2000), there is relatively little published on the impact of the macroeconomy on health insurance. Cawley and Simon (2005) examined the relationship between state unemployment rate and the probability of health insurance coverage in the Survey of Income and Program Participation (SIPP) and estimated that 984,000 Americans, nearly all of whom were adult men, lost health insurance due to macroeconomic conditions during the 2001 recession. Gilmer and Kronick (2009) use data from the Current Population Survey (CPS) from 1980 to 2008 to project that the Great Recession could increase the number of uninsured Americans by 6.9 million, but their model (which focuses on the influence of per capita health 
spending, income, demographics and time trends) does not take into account the focus of this paper, the unemployment rate. While there are annual national estimates of the percent and number of Americans who are uninsured (e.g. DeNavas-Walt et al., 2012; Fronstin, 2011), there has been no analysis of how health insurance coverage was impacted by increases in the unemployment rate around the time of the Great Recession. Trends in annual data may reflect the continuing long term decline in generosity of health insurance (Vistnes et al., 2012). This paper identifies the impact of worsening macroeconomic conditions (measured by the state monthly unemployment rate) using longitudinal data that allow us to investigate the heterogeneity of impact by demographic characteristics.

The relationship between unemployment rates and the probability of insurance coverage is likely to change over time in response to changes in health insurance markets and public health insurance programs; as a result, estimates from earlier papers may be out of date. For example, there have been declining trends (since the peaks reached in 2000) in both employer offers of health insurance (Vistnes et al., 2012) and employees covered through employer-sponsored insurance (Fronstin, 2011); these secular changes may have altered the relationship between the unemployment rate and health insurance. Moreover, each recession has distinct characteristics that may imply a different relationship between the unemployment rate and coverage. For example, the 2007-09 recession was characterized by a drop in home prices, which may have inhibited unemployed workers from moving to areas with more job opportunities, a phenomenon that some have called "house lock" (Ferreira et al., 2012). Likewise, extensions of the maximum duration of unemployment insurance benefits from 26 to up to 99 weeks in some states may have decreased the incentives for unemployed workers to quickly find new employment. Another relevant change is that, in 2009, Congress instituted a time-limited 65 percent subsidy for 
premiums associated with coverage through the Consolidated Omnibus Budget Reconciliation Act of 1985 (COBRA); this legislation gives qualifying workers and their families who would otherwise lose their health insurance the option to temporarily extend that coverage. The new subsidy was available for a maximum of 15 months to those who lost jobs between September 2008 and May 2010 (US DOL, 2011). By making it easier for newly unemployed workers to continue on the health insurance plan of their former employer, these subsidies likely weaken the correlation between the unemployment rate and the probability of health insurance.

For these reasons, the relationship between the macroeconomy and health insurance found in older data may not apply to the Great Recession. In addition, the severity of the Great Recession resulted in considerable variation in unemployment rates across states and over time, providing researchers with more power to accurately estimate the effect of the macroeconomy on health insurance. The purpose of this paper is to exploit that variation to generate accurate and up-to-date estimates of the impact of unemployment rates on health insurance coverage, both overall and by source of coverage, and for the entire population as well as for specific subgroups defined by gender, education, race, and age.

\section{Conceptual framework}

There are several mechanisms by which a high unemployment rate can result in the loss of employer-provided coverage. A high state unemployment rate is, by definition, associated with a higher probability that a resident of that state is unemployed. When those who were previously covered by employer-provided health insurance lose their jobs, they (and any dependents on the same policy) are likely to lose coverage from the former employer for themselves and for their dependents. Although COBRA allows eligible unemployed workers to 
temporarily purchase health insurance through their former employers, take-up rates are low because of the high cost (Collins et al., 2011; Lambrew, 2001). Some of those losing coverage may be able to shift to coverage provided by their spouses' plans.

High unemployment rates may lower the probability of employer-provided coverage even among those who remain employed. When labor demand falls because of a poor macroeconomy, total labor compensation will fall. If wages are costly to renegotiate, employers may reduce compensation by shifting a greater share of health insurance costs to employees. ${ }^{2}$ Employers may also reduce the quality of coverage or cease offering health insurance altogether (Marquis and Long, 2001).

Due to decreased labor demand, previously full-time workers may have their hours reduced to the point that they are no longer eligible for health insurance benefits. The lower labor income that accompanies higher unemployment rates could also have an income effect, reducing private purchases of individual health insurance.

Some individuals may gain health insurance coverage during periods of high unemployment if their incomes fall to a level that qualifies for Medicaid. Holahan and Garrett (2009), using CPS data from 1990-2003, estimate that an increase in unemployment of one percentage point would expand coverage through Medicaid by 0.2 percentage points for nonelderly adults and by 0.79 percentage points for children.

Based on this framework and the existing literature, we hypothesize that an increase in the unemployment rate decreases the probability of coverage through one's own employer. We predict that an increase in the unemployment rate increases the probability of coverage through public health insurance. We hypothesize that, on net, unemployment rate is negatively

\footnotetext{
${ }^{2}$ Elasticity estimates suggest that this mechanism should result in little decline in coverage; among those offered employer-sponsored health insurance, take-up falls by less than one-tenth of a percent when premiums increase by one percent (Chollet and Liu, 2006).
} 
correlated with the probability of health insurance coverage through any source for adults, but that for children the sign of the net effect on coverage is ambiguous because of the availability of public sources of coverage as family income falls.

\section{Methods}

We estimate logit models in which the dependent variables are indicator variables for health insurance coverage as well as for types of coverage. The regressor of interest is state monthly unemployment rate. Models also control for respondent age, marital status, education, and family size. All models control for both individual-specific and year-specific fixed effects; our identification of the effect of the state unemployment rate on the probability of health insurance coverage comes from variation within people over time in deviations of the state unemployment rate from the national mean for that year. The research design requires that we control for year fixed effects because even before the recession, health care costs were rising (Chernew et al., 2009), employer offers of health insurance were declining (Vistnes et al., 2012), and the percentage of Americans covered by employer-sponsored insurance was falling (Fronstin, 2011). Because our data contain multiple observations of the same person over time, we are also able to control for individual fixed effects so that our estimates are not influenced by any time invariant unobserved characteristics that affect health insurance status. For example, those with relatively low human capital may be less likely to be offered health insurance at their job, and may live in areas hit particularly hard by the Great Recession. We believe macroeconomic fluctuations to be largely exogenous, so do not think that such factors should 
have a large influence, but think it prudent to fully exploit the richness of the longitudinal data to eliminate the influence of any such time-invariant heterogeneity. ${ }^{3}$

In subsequent models we control for individual employment status in order to examine the pathways by which the macroeconomy acts on insurance status.

After first estimating a model for men and women pooled, we estimate models separately by gender because labor force participation and attachment and eligibility for publicly provided health insurance may differ by gender; for example, low-income pregnant women are eligible for Medicaid coverage. Men and women also tend to differ in the extent to which they have dependent coverage available through a spouse. We also examine whether the relationship between unemployment rate and insurance coverage differs across age, education, and race/ethnic group.

In general, when a microeconomic outcome is regressed on an aggregate regressor, unadjusted standard errors will be biased downwards, perhaps dramatically (Moulton, 1990). To account for the fact that our models regress individual outcomes on state-level measures of the macroeconomy, we follow standard practice and cluster standard errors by state.

To address the possibility of serial correlation in standard errors for observations within states over time (Bertrand et al., 2004), we bootstrap the standard errors within our logit specifications, selecting with replacement all observations in a particular state. Following Efron

\footnotetext{
${ }^{3}$ We have also estimated models without controlling for individual fixed effects and find smaller marginal effects on the unemployment rate for men, and in some cases larger marginal effects for women. For example, the association of a one percentage point increase in the state unemployment rate with the probability that men have coverage through any source is -1.67 percentage points in our fixed effects model and -0.74 percentage points in a model that does not control for fixed effects (both are statistically significant). For women, the comparable numbers are -0.50 and -0.45 (neither is statistically significant). The pattern of results is thus largely qualitatively similar whether we control for individual fixed effects or not, and moreover, the two sets of coefficients are not statistically significantly different from each other for 12 of the 14 cases. The results of models without controlling for individual fixed effects are available upon request.
} 
and Tibshirani (1993), we conduct 50 replications. As expected, this adjustment considerably increases the standard errors.

\section{Data: The Survey of Income and Program Participation (SIPP)}

The Survey of Income and Program Participation (SIPP) is a nationally representative sample of Americans over the age of 15 that consists of a series of panels that are up to 4 years in length with sample sizes ranging from approximately 12,000 to 40,000 households. The SIPP, which started in 1984, interviews households at 4-month intervals; thus, there exist up to 12 interviews for each individual. Although each SIPP interview collects data on the current month and, retrospectively, each of the 3 months between interviews, we use only the contemporaneous reports in order to avoid recall error.

This paper uses data from the 2004 and 2008 panels of the SIPP covering the period January 2004 through November 2010 (except for January 2008 to July 2008, which are not covered by either the 2004 or 2008 panel the SIPP), and covering all 50 states plus the District of Columbia. There are special considerations for each of these panels. The sample for the 2004 panel was cut in half in September 2006 in response to budgetary pressures. The 2008 panel is still in the field at the time of this writing, so only 7 waves of those data are available.

Each SIPP wave contains information on the respondent's insurance coverage and the source of their coverage, for a particular month. We study the following binary outcomes in the SIPP: whether one has health insurance coverage through any source, whether one receives health insurance coverage through one's own employer (this includes former employees continuing coverage through COBRA) ${ }^{4}$, whether one receives employer-provided health

\footnotetext{
${ }^{4}$ Among children (aged 17 and under), 1.81\% of the sample was recorded as having health insurance through their own employer. This was more common among children aged 15 (3.27\%), 16 (4.00\%) and 17 (4.47\%) but ranged
} 
insurance as a dependent, whether one has individually-purchased coverage, whether one is covered by government-provided health insurance (e.g. Medicaid or SCHIP), and whether one has coverage through some other source (not otherwise classified in the SIPP). Individuallypurchased plans are particularly interesting to examine because it is a source of coverage that is likely to expand under the PPACA.

The SIPP contains a wide variety of demographic and socioeconomic variables. In each regression, we control for the following characteristics that may influence insurance status: highest grade completed, age, number of children in the family, marital status, indicator variables for each individual, and indicator variables for each year. We exclude income from the set of regressors because wages and salary are determined simultaneously with fringe benefits such as health insurance. $^{5}$

The SIPP data are better suited to our research question than are data from the CPS, which is another household survey with state identifiers that is available in the public domain. CPS data are the basis of the standard annual estimates of health insurance coverage in the U.S. population (DeNavas-Walt et al., 2012). However, the CPS only records whether the respondent was covered by health insurance at any point in the past 12 months, making it impossible to determine whether the CPS respondent had coverage in any specific month. In contrast, the SIPP records an individual's insurance status in specific months, which enables one to match insurance status to the unemployment rate in that month. Another advantage is that the SIPP is longitudinal (whereas the CPS is cross-sectional); this feature allows us to estimate fixed effects

from $1.15 \%$ to $2.45 \%$ among those aged $0-14$ years. We assume that this is an error in the editing of the SIPP, and recode all such children as having employer-provided health insurance as a dependent.

${ }^{5}$ In a 2005 survey of health economists, $91 \%$ of health economists agreed that "Workers pay for employersponsored health insurance in the form of lower wages or reduced benefits." Six percent disagreed, and $4 \%$ said they did not know (Morrisey and Cawley, 2008). 
models that eliminate the bias that would otherwise be caused by individual-specific, timeinvariant heterogeneity.

The source for monthly state unemployment rates is the Bureau of Labor Statistics Local Area Unemployment Statistics Series. These state monthly unemployment rates are merged with the SIPP data using state identifiers. (Unlike earlier panels of the SIPP, in which less-populous states were not uniquely identified, the 2004 and 2008 panels identify state of residence for individuals in all 50 states plus the District of Columbia.) We control for individual and year fixed effects, so our identifying variation of unemployment on health insurance coverage is within people over time in deviations from the national mean for that year.

Our pooled SIPP data cover January 2004 through November 2010, with the exception of January through July of 2008, which was not covered by either the 2004 or 2008 panel of SIPP. The pooled data include the following numbers of person-month observations: 467,285 men, 510,334 women, and 416,648 children (aged 17 and younger).

\section{Empirical Results}

\section{Summary Statistics}

Table 1 lists summary statistics for the sample. On average during the time of our sample, the percent of respondents that were insured through any source was $78.6 \%$ for men, 83.0\% for women, and $85.5 \%$ for children. Men and women are roughly equally likely to be covered by employer-sponsored health insurance (65.2\% vs. 64.1\%) but men are more likely than women to have such coverage through their own employer ( $50.7 \%$ vs. $36.8 \%$ ) as opposed to as a dependent (14.5\% vs. 27.3\%). Among children, 51.2\% are covered by employer-provided health insurance as a dependent. Only $5.6 \%$ of men, $6.0 \%$ of women and $3.8 \%$ of children are 
covered by individually-purchased policies. Government health insurance programs are the source of coverage for $6.9 \%$ of men, $11.8 \%$ of women, and $27.6 \%$ of children.

\section{Logit Regressions}

We initially estimate the probability that an individual has health insurance coverage as a function of the unemployment rate and basic demographic characteristics while excluding employment status. Subsequently, we re-estimate our models controlling for employment status in order to investigate the extent to which that variable is a mechanism by which the unemployment rate affects health insurance. Each cell of each of our tables contains, from top to bottom, the sample size, the logit fixed effects coefficient, the standard error in parentheses, the marginal effect italicized in brackets, its standard errors italicized in parentheses, and the mean of the dependent variable.

The first set of rows in Table 2 presents results for all sample respondents under the age of $65^{6}$. The results indicate that a one percentage point increase in the unemployment rate has no significant impact on the probability of being insured either overall or through any specific source. However, these estimates based on the pooled sample, may obscure differences across gender and age. We next describe results estimated separately for adult men, adult women, and children.

The second set of rows of Table 2 presents results for men, which are consistent with our hypotheses that higher unemployment rates are associated with a lower probability of health insurance coverage through any source, the man's own employer, and individually purchased coverage. Specifically, a one-percentage-point higher unemployment rate is associated with a 1.67 percentage point (2.12\%) reduction in the probability of health insurance coverage through

\footnotetext{
${ }^{6}$ Children are excluded from the sample for the regressions in which the dependent variable concerns coverage through one's own employer.
} 
any source, a 1.00 percentage point $(1.97 \%)$ reduction in the probability of coverage through the man's own employer, and 1.44 percentage point (25.71\%) reduction in individually purchased coverage. The unemployment rate is not significantly associated with the probability of coverage through an employer as a dependent, government health insurance, or through any other source.

The third set of rows in Table 2, which correspond to women, indicate that there is no significant association between unemployment rate and health insurance coverage, either overall or through any specific source. This is not simply a result of large standard errors; when one compares the marginal effects for men and women for coverage through any source or through an employer, the marginal effects for women are generally smaller.

The fourth and bottom set of rows in Table 2, which correspond to children, show that the probability that a child has health insurance coverage through any source is not significantly correlated with the unemployment rate. However, a one-percentage-point higher unemployment rate is associated with a 1.52 percentage point (5.51\%) higher probability that a child is covered by government-provided health insurance. Together, these results confirm that government health insurance programs for children operate counter-cyclically, as intended; when unemployment rates rise, more children become enrolled in Medicaid and SCHIP, leaving the overall probability of coverage unaffected.

\section{Robustness Check and Extensions}

In this section, we explain the results of a variety of robustness checks and extensions, including adding additional controls for state characteristics, exploring whether the unemployment rate affects the reasons for uninsurance, and subgroup analyses by education, race, and age.Extension: Role of Employment Status (Own and Spouse's) 
In the main models of this paper, we sought to measure the total effect of unemployment rate on the probability of insurance (i.e., through all channels). Among the various ways that unemployment rate can affect coverage, the most important is likely by changing an individual's employment status.

To investigate whether changes in employment status fully explain the impact of the macroeconomy on insurance coverage, we measure the extent to which macroeconomic conditions are correlated with insurance status conditional on employment status. Specifically, we added to the set of regressors indicator variables for employment and unemployment (being out of the labor force is the reference category). Results are presented in Table 3 for men (top set of rows) and women (bottom set of rows). For both men and women we find the predictable result that employment is positively correlated, and unemployment is negatively correlated, with the probability of coverage. Also predictably, including employment status reduces the point estimate on unemployment rate. Recall that without controlling for employment status, a onepercentage point rise in unemployment was associated with a 1.67 percentage point decrease in the probability of health insurance coverage for men. After controlling for employment status, the decrease is 1.18 percentage points. When we examine the probability of coverage from specific sources, we find that adding controls for employment status to the regression for men having coverage through their own employer results in the point estimate of the coefficient on the unemployment rate falling by half and no longer being statistically significant. It has little impact on the association of the unemployment rate with men having individually-purchased coverage.

We also estimate models that control for spouse's employment status as well as the respondent's employment status; spouse's employment is relevant because one could receive 
coverage through the spouse's employer as a dependent. In results that are available upon request, we find that, for men, a one-percentage point rise in unemployment is associated with a 0.97 percentage point decrease in the probability of health insurance coverage and a 0.48 percentage point decrease in the probability of own employer sponsored coverage (both are statistically significant). A related question is whether the unemployment rate is associated with coverage among those who are always employed, change employment status, or are never employed. In tables available upon request, we find that the unemployment rate is negatively correlated with the probability of coverage among men who change employment status, and men who are always employed (a smaller marginal effect), but is not significantly correlated with the probability of coverage among men who are never employed. For women, unemployment rate is not significantly correlated with coverage in any of those groups. In summary, these findings confirm that a change in employment status is an important way in which the state unemployment rate affects the probability of health insurance coverage for both men and women, yet the unemployment rate still plays an important independent role for men.

\section{Extension: Unemployment Rate and the Reason One is Uninsured}

The SIPP questionnaire allows us to explore how the reasons for uninsurance vary with the macroeconomy. Specifically, the SIPP asks adults who lack health insurance the reasons that they are uninsured; respondents are allowed to indicate more than one reason. We restrict our sample to those who lack health insurance, and keep only the first month in which the individual reports being uninsured. We then estimate a series of logit models in which the dependent variable equals one if the respondent answers yes to a specific reason for being uninsured. The set of regressors includes the state monthly unemployment rate and the same 
regressors used in the earlier models, except that the models control for state fixed effects rather than individual fixed effects because we now use only one observation per uninsured person.

Results are presented in Table 4. For men, a one percentage point higher unemployment rate is associated with a 1.23 percentage point (1.55\%) increase in the probability that uninsurance was due to cost, and decreases in the probabilities that it was due to: insurance not being offered by an employer, the individual not being at the job long enough to qualify, and that insurance was not needed. For women, a one percentage point increase in the unemployment rate is associated with a 0.92 percentage point $(1.14 \%)$ increase in the probability that uninsurance is due to cost, and a reduction in the probability that uninsurance is due to not being at the job long enough to qualify. The fact that, as the unemployment rate rises, both men and women are less likely to attribute uninsurance to not being at the job long enough to qualify is consistent with both reduced hiring and the last hired being the first fired in recessions - both would result in fewer new workers waiting to qualify for health insurance.

These findings shed additional light on the other results in this paper. Specifically, they suggest that the earlier finding that men are less likely to have employer-provided health insurance in times of high unemployment is not due to employers dropping health insurance, but instead to men declining that offer due to cost.

\section{Extension: Subgroup Analysis by Education}

Recent economic studies have documented how the Great Recession differentially affected various groups in the population, and the evidence suggests differential impacts by education. For example, Elsby et al. (2010) find that unemployment during the Great Recession was particularly high among the less educated, and Farber (2011) finds that rates of job loss 
during the Great Recession were higher among less educated workers, but that unemployment of the better educated rose more than is typical during a recession.

As an extension, we conduct subgroup analyses by education. We estimate the main models (i.e. those from Table 2) for adults separately by education group: high school or less, some college, and bachelor's degree or more; the results are shown in Table 5. For men, a one percentage point rise in the unemployment rate is estimated to reduce the probability of coverage through any source by 1.73 percentage points (2.56\%) for those with a high school education or less, 1.37 percentage points (1.69\%) for those with some college, and 2.14 percentage points (2.32\%) for those with a bachelor's degree or more education. Each is significantly different from zero, but they are not significantly different from each other. However, the point estimates suggest that those with the lowest and highest levels of education were most likely to lose health insurance during the Great Recession.

Among women, even when models are estimated separately by educational attainment, we continue to find that the unemployment rate is not significantly associated with the probability of insurance coverage; the exception is that a one percentage point rise in unemployment is associated with a 1.63 percentage point (5.24\%) lower probability that women with a bachelor's degree or higher education receive employer-sponsored insurance as a dependent.

\section{Extension: Role of Spouse Education}

Spouse education is also potentially relevant, as it is likely correlated with the probability that one can acquire health insurance as a dependent on the spouse's health insurance. To investigate this, we added to the set of regressors interaction terms of unemployment rate with marital status and spouse's education dummies. We then re-conducted the subgroup analysis by 
education to see if the effects of the macroeconomy differ depending on marital status and spouses' education.

In results available upon request, we find that, for men with a high school degree or less, the impact of the unemployment rate on the probability of health insurance coverage is negative for those who are single or are married to a low-educated woman, but indistinguishable from zero for those married to a college-educated woman. Moreover, among men with a high school degree or less, the probability of having dependent coverage increases during periods of high unemployment rate, but only if their wife has some college or a college degree.

Men with a college degree do not exhibit the "protective" effect of a wife's college degree on probability of health insurance coverage that is found among men with a high school education.

\section{Extension: Subgroup Analyses by Race}

In other subgroup analyses, we estimate models separately by race (Table 6). The impact of unemployment rate on the probability of coverage is not significantly different for whites compared to African-Americans and Hispanics, but the pattern of point estimates suggests that the unemployment rate has a larger impact on health insurance coverage for whites. A one percentage point increase in the unemployment rate is associated with a 1.54 percentage point (1.84\%) lower probability that an adult white male has coverage from any source, and a 0.95 percentage point (1.51\%) reduction in the probability that an adult African-American or Hispanic male has coverage through any source. Among children, results indicate that whites gain health insurance during periods of high unemployment. Although the correlation is not statistically significant for African-American and Hispanic children, it is also not significantly different from the point estimate for white children (1.24 versus 1.38 percentage points). 


\section{Extension: Subgroup Analyses by Age}

Results for the average worker may obscure interesting differences across age groups. For example, younger workers may be hit harder if the last hired is the first fired, and older workers may have a harder time finding new employment after being laid off. We present results of models estimated separately by age group in Table 7. Among men, a one percentage point increase in the unemployment rate is associated with a decrease in the probability of coverage of 1.34 percentage points (1.93\%) for men aged 18-34, 1.56 percentage points (1.93\%) for men aged 35-49, and 2.50 percentage points (2.87\%) for men aged 50-64. Thus, the effect of the unemployment rate (in absolute terms) on the oldest group (50-64) is nearly double that on the youngest group (18-34). The magnitudes of the marginal effects for women also rise monotonically with age, but are in no case statistically significant.

\section{Extension: Comparison to Earlier Study}

The most logical comparison for this work is earlier work using the SIPP (Cawley and Simon, 2005, or CS), which used a similar method to predict the loss of health insurance coverage during the previous (2001) recession. To facilitate that comparison, we estimate identical models to those in the previous paper. Appendix Tables A1 - A3 (available as a supplemental file on the journal website) compare the estimates from the previous paper, which used SIPP data for 1990-2000 to predict the impact of the 2001 recession, to ones based on SIPP data for 2004-2010 that indicate the impact of the 2007-09 recession. Appendix Table A1 (comparable to Table 1 in CS), which provides results for men, shows that a percentage point increase in the unemployment rate was associated with a greater increase in the probability of uninsurance in the more recent recession: 1.3 percentage points compared to 0.7 percentage points. For women (Appendix Table A2, comparable to Table 2 in CS), the decrease in the 
probability of employer coverage in one's own name that is associated with a one percentage point increase in the unemployment rate fell from 0.07 percentage points in the earlier data to a non-significant 0.01 percentage points. For children (Appendix Table A3, comparable to Table 3 in CS) the increase in the probability of Medicaid coverage associated with a one percentage point increase in the unemployment rate remained roughly constant: 1.04 percentage points in the earlier sample and 1.01 percentage points in the current sample.

Overall, the comparison of the current recession to previous data suggests that the health insurance coverage of men is now more vulnerable to changes in the unemployment rate. The increase in the probability of being uninsured associated with a one percentage point increase in the unemployment rate is almost twice as high in the Great Recession (1.3) than in the previous data (0.7); however, we caution that this difference is not statistically significant and that this result is only suggestive. Such a difference could be the result of differences in the characteristics of recessions; e.g. the 2007-09 recession hit male-dominated sectors such as finance, banking, construction, and manufacturing particularly hard, leading it to be nicknamed the "man-cession" (Elsby et al., 2010). ${ }^{7}$

A comparison of the results for women yields little evidence that the unemployment rate has a different impact in this recession compared to prior periods. For example, the difference in marginal effects of unemployment rate on the probability of coverage through a woman's own employer is not statistically significant and also is not economically meaningful in terms of the difference in its magnitude.

Robustness Check: Employment Rate Instead of Unemployment Rate

\footnotetext{
${ }^{7}$ Elsby et al. (2010) note that in general recessions tend to lead to greater increases in unemployment for men than women, in part because the industries in which male workers are concentrated (e.g. construction, manufacturing) are particularly pro-cyclical.
} 
The state unemployment rate is the primary measure used in the large literature on the macroeconomy and health (see e.g. Ruhm, 2006) and thus is the logical measure to use in this context. However, one might be concerned that some of the variation in unemployment rate is due to job-seekers becoming discouraged and ceasing to look for work, leading to their removal from the denominator. Interestingly, Farber (2011) finds no evidence that job losers are more likely to become discouraged workers during recessions, including the Great Recession. Nevertheless, to investigate the sensitivity of our results, we re-estimate our models using the employment rate rather than the unemployment rate; the results are provided in Appendix Table 4. We find that a one percentage point increase in the employment rate is associated with an increase in the probability of health insurance coverage through any source of 0.09 percentage points for men and 0.21 percentage points for women. Overall, while the major conclusions remain the same (the probability of health insurance coverage is correlated with the macroeconomy), the specific results are somewhat sensitive to which measure of the macroeconomy is used.

\section{Robustness Check: Additional Controls for State Characteristics}

In a previous study (Cawley and Simon, 2005) we controlled for three other measures of state-level heterogeneity: the percent of the workforce that is unionized in that state, the Medicare hospital wage index, and the generosity of public health insurance programs. None were found to affect the results, and so were excluded from the models in this paper because they are not integral to an analysis of the recession itself and could even be mechanisms that are affected by a worsening economic climate. As a robustness check, however, we included the three variables in the set of regressors; in results that are available upon request, we find that this does not change our results in any meaningful way, with the exception that the effect of the 
unemployment rate on government provided insurance among children becomes statistically insignificant.

\section{Discussion}

The Great Recession of 2007-09 is the longest and deepest macroeconomic downturn in the United States since 1933. This paper documents the impact of higher unemployment rates on one important outcome: health insurance coverage.

We find substantial heterogeneity in this relationship across gender, education, race, and age, as well as source of insurance. For men, a one percentage point rise in the unemployment rate is associated with a $1.67(2.12 \%)$ percentage point reduction in coverage through any source. Point estimates suggest that this impact for men is greatest among whites (relative to AfricanAmericans and Hispanics) and older (50-64) individuals, but differences among subgroups are in most cases not statistically significant.

We also find that men's probability of coverage through individually-purchased plans declines with the unemployment rate. Thus, the decreased demand due to lower income may outweigh the increased demand for individual plans among those losing jobs; this could in part be due to temporary COBRA subsidies that kept newly-separated workers on their previous employer-provided plans (Moriya and Simon, 2013). Our findings concerning individuallypurchased plans are timely because the PPACA seeks to expand this source of coverage; men may need subsidies to continue purchasing individual plans during periods of high unemployment.

In contrast to the findings for men, among women the unemployment rate is in almost no case significantly correlated with the probability of coverage, and the point estimates of the marginal effects are much smaller than those for men. For children, a one percentage point 
higher unemployment rate is associated with a 1.52 percentage point (5.51\%) higher probability of public health insurance coverage, with the result that there is no statistically significant effect on the probability of health insurance coverage through any source. These findings confirm that government health insurance programs work counter-cyclically to protect children from losing health insurance during macroeconomic downturns.

As hypothesized, the loss of employment is an important pathway through which a higher unemployment rate leads to a lower probability of health insurance coverage for men. However, even controlling for employment status, men still face a 1.18 percentage point lower probability of coverage when the unemployment rate rises by 1 percentage point. This may be due to employers dropping coverage, employers cutting hours such that some men no longer qualify for health insurance, employers raising workers' share of the overall premium so more male workers decline coverage, or lower incomes that result in fewer purchases of individual coverage.

We investigate the reasons for a lack of coverage, and find that when the unemployment rate is high, the uninsured are more likely to report that their uninsurance is due to the high cost of coverage, which is consistent with employers shifting more of the premium to workers and lower family incomes being important mechanisms for the relationship between the unemployment rate and the probability of coverage. Interestingly, during periods of high unemployment, men are less likely to attribute uninsurance to employers not offering coverage.

This paper's estimates of the correlation between health insurance coverage and unemployment rate during 2004-2010 can be used to estimate the number of Americans who lost health insurance during the Great Recession, which lasted from December 2007 until June 2009. During that period, the national unemployment rate rose from 5.0\% to 9.5\% (U.S. Department of 
Labor, 2011). ${ }^{8}$ Based on this change, our regression results, and Census estimates of the U.S. population of men aged 18-64, and women aged 18-64 in the year 2008 (U.S. Census Bureau, 2011), we estimate that roughly 9.3 million adult Americans lost health insurance during the Great Recession. This is the difference in the number of adult Americans who had health insurance coverage at the macroeconomic peak in December 2007 compared to the trough in June 2009; the number who ever lost health insurance during the Great Recession is undoubtedly higher due to the fact that there is churning in the ranks of the uninsured (Swartz, 1994). This macroeconomic impact fell much more heavily on men; the 9.3 million total includes 7.1 million men and 2.2 million women. Thus, the Great Recession lived up to its name; for comparison, during the 2001 recession, 984,000 adult Americans lost health insurance (Cawley and Simon, 2005). The difference in estimates is driven by both a much greater increase in unemployment rate (a 4.5 percentage point increase during the Great Recession compared to a 1.3 percentage point increase during the 2001 recession), and a larger effect on men of each percentage point rise in unemployment. In contrast to adults, our point estimates imply that 4.2 million children under the age of 18 gained health insurance during the Great Recession. Combining adults and children, we estimate that on net 5.1 million Americans lost health insurance coverage.

We caution that the 95\% confidence intervals around our aggregate estimates are very large; for men it ranges between 11.9 million and 2.4 million losing health insurance, for women it ranges between 5.2 million losing coverage and 0.9 million gaining it, and for children it ranges between 73,000 and 8.4 million gaining coverage. The bootstrapped 95\% confidence interval for the effect on adults is between 16.2 million and 2.5 million losing coverage, and the

\footnotetext{
${ }^{8}$ The national unemployment rate continued to rise after what the NBER classifies as the end of the 2009 recession (peaking at $10.1 \%$ in October 2009), but we consider the trough of the economy to be that determined by the NBER.
} 
corresponding confidence interval when including adults and children is between 13.7 million losing coverage to 3.5 million gaining coverage.

Our estimate that 9.3 million adult Americans lost health insurance during the Great Recession is similar to the calculation reported by the Commonwealth Fund (based on Commonwealth Biennial Health Insurance Surveys) that, between 2008 and 2010, 9 million adults lost health insurance following the loss of a job (Collins et al., 2011); however, our estimate also includes those who lost coverage without changing employment status. Our estimate is also higher than that of Gilmer and Kronick (2009), who estimate, using a model that does not consider unemployment rate, that 6.9 million Americans lost health insurance during the Great Recession.

In the future, the reforms passed by the U.S. Congress in the 2010 PPACA will likely moderate the impact of the unemployment rate on the probability of insurance coverage. The PPACA offers incentives for employers to offer, and individuals to take up, coverage; provides subsidies for coverage of low-income families through public and private policies; and changes the regulation of health insurance prices in the individual market. Many features of the law are expected to cushion the impact of future recessions on health insurance coverage, particularly for adults. For example, the availability of exchanges for individual insurance together with limits on raising premia with age could reduce the impact of recession on the health insurance status of older workers. As the various components of the PPACA are implemented, it will become possible for researchers to more accurately estimate how reforming the current system of health insurance in the US will affect the association of the unemployment rate with the probability of uninsurance and the functioning of the social safety net. 


\section{Works Cited}

Bertrand, M., E. Duflo, and S. Mullainathan. 2004. "How much should we trust differences-indifferences estimates?" Quarterly Journal of Economics 119(1): 249-276.

Card, David, Carlos Dobkin and Nicole Maestas. 2009. “Does Medicare Save Lives?" Quarterly Journal of Economics, 124(2): 597-636.

Cawley, John and Kosali I. Simon. 2005. "Health Insurance Coverage and the Macroeconomy." Journal of Health Economics, 24: 299-315.

Charles, Kerwin and Philip DeCicca. 2008. "Local labour market fluctuations and health: Is there a connection and for whom?" Journal of Health Economics, 27(6): 1332-1350.

Chernew, Michael E., Richard A. Hirth and David M. Cutler. 2009. "Increased Spending on Health Care: Long-Term Implications for the Nation." Health Affairs, 28(5): 1253-1255.

Chollet, Deborah and Su Liu. 2006. Price and Income Elasticity of the Demand for Health Insurance and Health Care Services: A Critical Review of the Literature. Available at http://www.mathematica-mpr.com/publications/pdfs/priceincome.pdf

Collins, Sara R., Michelle M. Doty, Ruth Robertson, and Tracy Garber. 2011. "Help on the Horizon: How the Recession Has Left Millions of Workers Without Health Insurance, and How Health Reform Will Bring Relief; Findings from The Commonwealth Fund Biennial Health Insurance Survey of 2010."

DeNavas-Walt, Carmen, Bernadette D. Proctor, and Jessica C. Smith. 2012. U.S. Census Bureau, Current Population Reports, P60-243, Income, Poverty, and Health Insurance Coverage in the United States: U.S. Government Printing Office, Washington, DC.

Doyle, Joseph J. 2005. "Health Insurance, Treatment, and Outcomes: Using Auto Accidents as Health Shocks." Review of Economics and Statistics, 87(2): 256-270.

Efron, Bradley, and Tibshirani, Robert J., 1993. An Introduction to the Bootstrap. Chapman \& Hall, New York.

Elsby, Michael, Bart Hobjin, and Aysegul Sahin. 2010. “The Labor Market in the Great Recession," Brookings Papers on Economic Activity, 41(1): 1-69.

Farber, Henry S. 2011. "Job Loss in the Great Recession: Historical Perspective from the Displaced Workers Survey, 1984-2010.” National Bureau of Economic Research Working Paper \#17040.

Federal Reserve Bank of Minneapolis. 2011. "The Recession and Recovery in Perspective." World wide web content. http://www.minneapolisfed.org/publications_papers/studies/recession_perspective/index. cfm Accessed October 20, 2011.

Ferreira, Fernando, Joseph Gyourko and Joseph Tracy. 2012. "Housing Busts and Household Mobility: An Update.” Economic Policy Review, 18 (3): 1-15.

Finkelstein, Amy, Sarah Taubman, Bill Wright, Mira Bernstein, Jonathan Gruber, Joseph P. Newhouse, Heidi Allen, Katherine Baicker, The Oregon Health Study Group. 2012. "The Oregon Health Insurance Experiment: Evidence from the First Year." The Quarterly Journal of Economics, 127 (3): 1057-1106.

Freeman, Joseph D., Srikanth Kadiyala, Janice F. Bell, and Diane P. Martin. 2008. "The Causal Effect of Health Insurance on Utilization and Outcomes in Adults: A Systematic Review of US Studies.” Medical Care, 46(10): 1023-1032. 
Fronstin, Paul. 2011. Sources of Health Insurance and Characteristics of the Uninsured: Analysis of the March 2011 Current Population Survey" EBRI Issue Brief \#362, available at http://www.ebri.org/pdf/briefspdf/EBRI_IB_09-2011_No362_Uninsured1.pdf

Gilmer, Todd P., and Richard G. Kronick. 2009. "Hard Times And Health Insurance: How Many Americans Will Be Uninsured By 2010?” Health Affairs, 28(4): w573-w577.

Gross, Tal, and Matthew J. Notowidigdo. 2011. "Health insurance and the consumer bankruptcy decision: Evidence from expansions of Medicaid." Journal of Public Economics, 95(7-8): 767-778.

Holahan, John and A. Bowen Garrett. 2009. "Rising Unemployment, Medicaid and the Uninsured." Kaiser Family Foundation report. http://www.kff.org/uninsured/upload/7850.pdf

Himmelstein, David U., Deborah Thorne, Elizabeth Warren, and Steffie Woolhandler. 2009. "Medical Bankruptcy in the United States, 2007: Results of a National Study." American Journal of Medicine, 122(8): 741-746.

Hurd, Michael D. and Susann Rohwedder. 2010. "Effects of the Financial Crisis and Great Recession on American Households." National Bureau of Economic Research Working Paper \#16407.

Lambrew, JeanneM. 2001. How the Slowing U.S. Economy Threatens Employer-Based Health Insurance. The Commonwealth Fund, New York, November.

Marquis, M.Susan, Long, Stephen H. 2001. "Employer health insurance and local labor market conditions." International Journal of Health Care Finance and Economics 1(3): 273292.

McWilliams, J. Michael. 2009. "Health Consequences of Uninsurance among Adults in the United States: Recent Evidence and Implications.” Milbank Quarterly, 87(2): 443-494.

Moriya, Asako and Kosali Simon. 2013. "Impact of Premium Subsidies on the Take-up of Health Insurance: Evidence from the 2009 American Recovery and Reinvestment Act (ARRA)." Working paper.

Morrisey, Michael A., and John Cawley. 2008. "Health Economists' Views of Health Policy." Journal of Health Politics, Policy, and Law, 33(4): 707-724.

Moulton, BrentR., 1990. "An illustration of a pitfall in estimating the effects of aggregate variables in micro units.” Review of Economics and Statistics 72(2): 334-338.

NBER Business Cycle Dating Committee. 2011. "US Business Cycle Expansions and Contractions." World wide web content. http://www.nber.org/cycles.html Accessed October 20, 2011.

Ruhm, Christopher J. 2000. “Are recessions good for your health?” Quarterly Journal of Economics 115(2):617-650.

Ruhm, Christopher J. 2003. "Good times make you sick.” Journal of Health Economics 24(4): 637-658.

Ruhm, Christopher J. 2006. "Macroeconomic Conditions, Health and Mortality.” In: Jones, Andrew M. (ed.) Elgar Companion to Health Economics. Cheltenham, UK: Edward Elgar Publishing.

Swartz, Katherine. 1994. "Dynamics of People Without Health Insurance: Don't Let the Numbers Fool You," Journal of the American Medical Association, Vol. 271, No. 1 (Jan. 5, 1994), pp. 64-66. 
U.S. Census Bureau. 2011. "National Intercensal Estimates (2000-2010). World wide web content. http://www.census.gov/popest/intercensal/national/nat2010.html Accessed Oct 21, 2011.

U.S. Department of Labor, Bureau of Labor Statistics. 2011. "Labor Force Statistics from the Current Population Survey." World wide web content. http://data.bls.gov/timeseries/LNS14000000 Accessed October 21, 2011.

Vistnes, Jessica, Alice Zawacki, Kosali Simon, and Amy Taylor. 2012. "Declines in Employer Sponsored Coverage Between 2000 and 2008: Offers, Take-Up, Premium Contributions and Dependent Options." Health Services Research, 47 (3 pt1): 919-938. 
Table 1. Means of Key Variables

\begin{tabular}{lrrr}
\hline & Men & Women & Children \\
\hline Health Insurance Status & & & \\
Indicator: covered by any HI & 0.786 & 0.830 & 0.855 \\
Indicator: covered by own employer HI & 0.507 & 0.368 & \\
Indicator: covered by employer HI as a dependent & 0.145 & 0.273 & 0.512 \\
Indicator: covered by individually purchased insurance & 0.056 & 0.060 & 0.038 \\
Indicator: covered by government HI & 0.069 & 0.118 & 0.276 \\
Indicator: covered by other insurance & 0.009 & 0.011 & 0.028 \\
Employment Status & & & \\
Indicator: employed & 0.794 & 0.681 & \\
Indicator: unemployed & 0.045 & 0.038 & \\
Indicator: not in a labor force & 0.161 & 0.281 & \\
Measures of Macroeconomy & & & \\
State monthly unemployment rate & 6.57 & 6.56 & 6.50 \\
State annual GSP & 42.1 & 42.1 & 42.1 \\
\hline Number of observations & 467,285 & 510,334 & 416,648 \\
\hline
\end{tabular}

Notes: Data: pooled 2004-2010 waves of the SIPP. The sample consists of: column 1: all men between the ages of 18 and 64 ; column 2: all women between the ages of 18 and 64; column 3: all children under the age of 18 . We use the data for period from January 2004 to November 2010 except for January 2008 to July 2008, which are not covered by either 2004 or 2008 panel the SIPP. 
Table 2. Probability of Health Insurance Coverage, Logit Regression (controlling for person- and year-specific fixed effects)

\begin{tabular}{|c|c|c|c|c|c|c|}
\hline & Any source & $\begin{array}{l}\text { Employer own } \\
\text { coverage }\end{array}$ & $\begin{array}{c}\text { Employer } \\
\text { dependent } \\
\text { coverage }\end{array}$ & $\begin{array}{c}\text { Individually } \\
\text { purchased } \\
\text { coverage }\end{array}$ & $\begin{array}{c}\text { Government } \\
\text { provided }\end{array}$ & Other coverage \\
\hline ALL & $(\mathrm{N}=1,394,267)$ & $(\mathrm{N}=977,619)$ & $(\mathrm{N}=1,394,267)$ & $(\mathrm{N}=1,394,267)$ & $(\mathrm{N}=1,394,267)$ & $(\mathrm{N}=1,394,267)$ \\
\hline \multirow[t]{4}{*}{ unemployment rate } & -0.0124 & -0.0254 & -0.0039 & -0.0253 & 0.0280 & 0.0034 \\
\hline & $(0.015)$ & $(0.016)$ & $(0.018)$ & $(0.020)$ & $(0.022)$ & $(0.029)$ \\
\hline & {$[-0.0030]$} & {$[-0.0036]$} & {$[-0.0009]$} & {$[-0.0041]$} & {$[0.0069]$} & [0.0008] \\
\hline & $(0.004)$ & $(0.002)$ & $(0.004)$ & $(0.004)$ & $(0.006)$ & $(0.007)$ \\
\hline mean of dependent variable & 0.823 & 0.435 & 0.301 & 0.052 & 0.149 & 0.015 \\
\hline MEN & $(\mathrm{N}=467,285)$ & $(\mathrm{N}=467,285)$ & $(\mathrm{N}=467,285)$ & $(\mathrm{N}=467,285)$ & $(\mathrm{N}=467,285)$ & $(\mathrm{N}=467,285)$ \\
\hline \multirow[t]{4}{*}{ unemployment rate } & $-0.0707 * * *$ & $-0.0431 * * *$ & 0.0180 & $-0.0623 * *$ & 0.0026 & -0.0786 \\
\hline & $(0.023)$ & $(0.015)$ & $(0.029)$ & $(0.027)$ & $(0.038)$ & $(0.055)$ \\
\hline & {$[-0.0167]$} & {$[-0.0100]$} & {$[0.0045]$} & {$[-0.0144]$} & [0.0002] & {$[-0.0084]$} \\
\hline & $(0.006)$ & $(0.004)$ & $(0.008)$ & $(0.007)$ & $(0.004)$ & $(0.011)$ \\
\hline mean of dependent variable & 0.786 & 0.507 & 0.145 & 0.056 & 0.069 & 0.009 \\
\hline WOMEN & $(\mathrm{N}=510,334)$ & $(\mathrm{N}=510,334)$ & $(\mathrm{N}=510,334)$ & $(\mathrm{N}=510,334)$ & $(\mathrm{N}=510,334)$ & $(\mathrm{N}=510,334)$ \\
\hline \multirow[t]{4}{*}{ unemployment rate } & -0.0214 & -0.0037 & -0.0189 & -0.0142 & -0.0047 & 0.0642 \\
\hline & $(0.017)$ & $(0.019)$ & $(0.019)$ & $(0.032)$ & $(0.025)$ & $(0.062)$ \\
\hline & {$[-0.0050]$} & {$[-0.0007]$} & {$[-0.0041]$} & {$[-0.0021]$} & {$[-0.0010]$} & {$[0.0160]$} \\
\hline & $(0.004)$ & $(0.004)$ & $(0.004)$ & $(0.003)$ & $(0.006)$ & $(0.011)$ \\
\hline mean of dependent variable & 0.830 & 0.368 & 0.273 & 0.060 & 0.118 & 0.011 \\
\hline CHILDREN & $(\mathrm{N}=416,648)$ & & $(\mathrm{N}=416,648)$ & $(\mathrm{N}=416,648)$ & $(\mathrm{N}=416,648)$ & $(\mathrm{N}=416,648)$ \\
\hline \multirow[t]{4}{*}{ unemployment rate } & 0.0533 & & -0.0026 & -0.0002 & $0.0609 * *$ & 0.0003 \\
\hline & $(0.033)$ & & $(0.034)$ & $(0.044)$ & $(0.028)$ & $(0.035)$ \\
\hline & {$[0.0126]$} & & {$[-0.0006]$} & {$[0.0000]$} & [0.0152] & {$[0.0001]$} \\
\hline & $(0.006)$ & & $(0.008)$ & $(0.006)$ & $(0.006)$ & $(0.009)$ \\
\hline mean of dependent variable & 0.855 & & 0.512 & 0.038 & 0.276 & 0.028 \\
\hline
\end{tabular}

Notes: (1) Cells of the table contain: coefficient, bootstrapped standard errors in parentheses, marginal effects italicized in brackets, and bootstrapped standard errors of marginal effects italicized in parentheses. (2) Superscripted notations next to the coefficients indicate the level of statistical significance from a two-tailed t-test. *** denotes the 1\% level, ** denotes the 5\% level and * denotes the 10\% level. (3) Bootstrapped standard errors are clustered at the state level. (4) Data: pooled 2004-2010 waves of the SIPP. The sample consists of: row 1: all non-elderly under the age of 65 (except columns 2 and 4: all non-elderly adults between the ages of 18 and 64 regardless of employment status); row 2; all men between the ages of 18 and 64 regardless of employment status; row 3: all women between the ages of 18 and 64 regardless of employment status, and ; row 4: all children under the age of 18. (5) Dependent variables - column 1: indicator variable that equals 1 if individual covered by health insurance from any source and 0 otherwise; column 2 : indicator variable that equals 1 if individual is covered by employer health insurance in own name and 0 otherwise; column 3: indicator variable that equals 1 if individual is covered by employer health insurance as a dependent and 0 otherwise; column 4: indicator variable that equals 1 if individual is covered by individually purchased health insurance and 0 otherwise; column 5: indicator variable for any type of government-provided health insurance; column 6: indicator variable that equals 1 if individual is covered by health insurance but do not report the kind of insurance. (6) Other regressors are individual fixed effects, year-specific fixed effects, highest grade completed, marital status, presence of children in the family, and age. 
Table 3. Probability of Health Insurance Coverage Logit Regression (controlling for person- and year-specific fixed effects)

With controls for labor force status

\begin{tabular}{|c|c|c|c|c|c|c|c|c|c|c|}
\hline & \multicolumn{2}{|c|}{ Any source } & \multicolumn{2}{|c|}{$\begin{array}{c}\text { Employer own } \\
\text { coverage }\end{array}$} & \multicolumn{2}{|c|}{$\begin{array}{l}\text { Employer } \\
\text { dependent } \\
\text { coverage }\end{array}$} & \multicolumn{2}{|c|}{$\begin{array}{l}\text { Individually } \\
\text { purchased } \\
\text { coverage }\end{array}$} & \multicolumn{2}{|c|}{$\begin{array}{l}\text { Government } \\
\text { provided }\end{array}$} \\
\hline MEN & \multicolumn{2}{|c|}{$(\mathrm{N}=467,285)$} & \multicolumn{2}{|c|}{$(\mathrm{N}=467,285)$} & \multicolumn{2}{|c|}{$(\mathrm{N}=467,285)$} & \multicolumn{2}{|c|}{$(\mathrm{N}=467,285)$} & \multicolumn{2}{|c|}{$(\mathrm{N}=467,285)$} \\
\hline \multirow{4}{*}{ unemployment rate } & -0.0564 & $* *$ & -0.0255 & & 0.0159 & & -0.0658 & $* *$ & -0.0017 & \\
\hline & $(0.021)$ & & $(0.022)$ & & $(0.030)$ & & $(0.028)$ & & $(0.043)$ & \\
\hline & {$[-0.0118]$} & & {$[-0.0043]$} & & [0.0039] & & {$[-0.0164]$} & & {$[-0.0002]$} & \\
\hline & $(0.005)$ & & $(0.003)$ & & $(0.007)$ & & $(0.007)$ & & $(0.005)$ & \\
\hline \multirow[t]{3}{*}{ Indicator for having a job } & 0.554 & $* * *$ & 1.801 & $* * *$ & -0.301 & $* * *$ & -0.688 & $* * *$ & -1.076 & $* * *$ \\
\hline & $(0.042)$ & & $(0.052)$ & & $(0.056)$ & & $(0.047)$ & & $(0.059)$ & \\
\hline & [0.121] & & [0.377] & & {$[-0.0739]$} & & {$[-0.170]$} & & {$[-0.147]$} & \\
\hline \multirow[t]{3}{*}{ Indicator for being unemployed } & -0.623 & $* * *$ & -0.412 & $* * *$ & -0.0302 & $* * *$ & -0.115 & $* * *$ & -0.430 & $* * *$ \\
\hline & $(0.031)$ & & $(0.073)$ & & $(0.041)$ & & $(0.066)$ & & $(0.067)$ & \\
\hline & [-0.142] & & {$[-0.0764]$} & & {$[-0.0073]$} & & {$[-0.0287]$} & & {$[-0.0645]$} & \\
\hline WOMEN & $(\mathrm{N}=510,3$ & & $(\mathrm{N}=510,3$ & & $(\mathrm{N}=510,3$ & & $(\mathrm{N}=510$, & 34) & $(\mathrm{N}=510,3$ & \\
\hline \multirow[t]{4}{*}{ unemployment rate } & -0.0139 & & 0.0145 & & -0.0200 & & -0.0237 & & -0.0117 & \\
\hline & $(0.020)$ & & $(0.019)$ & & $(0.022)$ & & $(0.026)$ & & $(0.029)$ & \\
\hline & {$[-0.0028]$} & & {$[0.0019]$} & & {$[-0.0049]$} & & {$[-0.0049]$} & & {$[-0.0029]$} & \\
\hline & $(0.005)$ & & $(0.002)$ & & $(0.005)$ & & $(0.005)$ & & $(0.007)$ & \\
\hline \multirow[t]{3}{*}{ Indicator for having a job } & 0.450 & $* * *$ & 2.210 & $* * *$ & -0.409 & $* * *$ & -0.696 & $* * *$ & -0.826 & $* * *$ \\
\hline & $(0.025)$ & & $(0.055)$ & & $(0.040)$ & & $(0.046)$ & & $(0.047)$ & \\
\hline & [0.0919] & & [0.404] & & {$[-0.0977]$} & & {$[-0.140]$} & & {$[-0.202]$} & \\
\hline \multirow[t]{3}{*}{ Indicator for being unemployed } & -0.438 & $* * *$ & -0.166 & $* * *$ & -0.129 & $* * *$ & -0.152 & $* * *$ & -0.170 & $* * *$ \\
\hline & $(0.047)$ & & $(0.059)$ & & $(0.049)$ & & $(0.063)$ & & $(0.048)$ & \\
\hline & {$[-0.0944]$} & & {$[-0.0227]$} & & {$[-0.0315]$} & & {$[-0.0324]$} & & {$[-0.0422]$} & \\
\hline
\end{tabular}

Notes: (1) See Notes (1)-(6) under Table 2.

(2) Model includes as regressors, in addition to variables listed under Note 6 of Table 2, an indicator for being employed, and an indicator for being unemployed .

(3) The means of dependent variables are the same as those in Table 2. 
Table 4: Reason a Person is Uninsured, as a Function of the Unemployment Rate Logit Regression (controlling for person- and year-specific fixed effects)

\begin{tabular}{|c|c|c|c|c|c|c|}
\hline & $\begin{array}{l}\text { too expensive, } \\
\text { can't } \\
\text { afford }\end{array}$ & $\begin{array}{c}\text { HI not offered } \\
\text { by } \\
\text { employer }\end{array}$ & $\begin{array}{c}\text { not at job long } \\
\text { enough to } \\
\text { qualify }\end{array}$ & $\begin{array}{c}\text { job layoff, job } \\
\text { loss, } \\
\text { unemployment }\end{array}$ & $\begin{array}{l}\text { not eligible- } \\
\text { part } \\
\text { time or temp }\end{array}$ & $\begin{array}{l}\text { haven't needed } \\
\text { health } \\
\text { insurance }\end{array}$ \\
\hline MEN & $(\mathrm{N}=28,645)$ & $(\mathrm{N}=28,645)$ & $(\mathrm{N}=28,645)$ & $(\mathrm{N}=28,645)$ & $(\mathrm{N}=28,645)$ & $(\mathrm{N}=28,645)$ \\
\hline unemployment rate & $\begin{array}{l}0.0795 * * \\
(0.030)\end{array}$ & $\begin{array}{c}-0.0883 * * \\
(0.040)\end{array}$ & $\begin{array}{l}-0.108 \quad * * * \\
(0.036)\end{array}$ & $\begin{array}{l}0.0210 \\
(0.037)\end{array}$ & $\begin{array}{r}-0.0004 \\
(0.047)\end{array}$ & $\begin{array}{l}-0.128 \quad * * * \\
(0.037)\end{array}$ \\
\hline mean of dependent variable & $\begin{array}{r}{[0.0123]} \\
0.792\end{array}$ & $\begin{array}{r}{[-0.0142]} \\
0.208\end{array}$ & $\begin{array}{r}{[-0.0082]} \\
0.089\end{array}$ & $\begin{array}{r}{[0.0011]} \\
0.064\end{array}$ & $\begin{array}{r}{[-0.00001]} \\
0.029\end{array}$ & $\begin{array}{r}{[-0.0048]} \\
0.044\end{array}$ \\
\hline WOMEN & $(\mathrm{N}=25,891)$ & $(\mathrm{N}=25,891)$ & $(\mathrm{N}=25,891)$ & $(\mathrm{N}=25,891)$ & $(\mathrm{N}=25,891)$ & $(\mathrm{N}=25,891)$ \\
\hline unemployment rate & $\begin{array}{l}0.0716 \text { ** } \\
(0.028)\end{array}$ & $\begin{array}{r}-0.0684 \\
(0.044)\end{array}$ & $\begin{array}{rl}-0.116 & * * * \\
(0.043) & \end{array}$ & $\begin{array}{r}0.0306 \\
(0.030)\end{array}$ & $\begin{array}{r}-0.0274 \\
(0.041)\end{array}$ & $\begin{array}{r}-0.0958 \\
(0.068)\end{array}$ \\
\hline mean of dependent variable & $\begin{array}{r}{[0.0092]} \\
0.807 \\
\end{array}$ & $\begin{array}{r}{[-0.0098]} \\
0.172 \\
\end{array}$ & $\begin{array}{r}{[-0.0073]} \\
0.072\end{array}$ & $\begin{array}{r}{[0.0013]} \\
0.049\end{array}$ & $\begin{array}{r}{[-0.0009]} \\
0.036\end{array}$ & $\begin{array}{r}{[-0.0025]} \\
0.032\end{array}$ \\
\hline
\end{tabular}

Notes: (1) See Notes (1)-(3) under Table 2.

(2) Sample is limited to the first observed month of being uninsured for each individual in the SIPP (2004-2010).

(3) Dependent variables - column 1: indicator variable that equals 1 if the reason a person is uninsured is "too expensive, can't afford" and 0 otherwise; column 2: indicator variable that equals 1 if the reason a person is uninsured is "HI not offered by employer" and 0 otherwise; column 3: indicator variable that equals 1 if the reason a person is uninsured is "not at job long enough to qualify" and 0 otherwise; column 4: indicator variable that equals 1 if the reason a person is uninsured is "job layoff, job loss,

unemployment" and 0 otherwise; column 5: indicator variable that equals 1 if the reason a person is uninsured is "not eligible-part time or temp" and 0 otherwise; column 6: indicator variable that equals 1 if the reason a person is uninsured is "haven't needed health insurance" and 0 otherwise.

(4) Other regressors are state fixed effects, year-specific fixed effects, highest grade completed, marital status, presence of children in the family, and age. 
Table 5. Probability of Health Insurance Coverage, by Education: Men

Logit Regression (controlling for person- and year-specific fixed effects)

\begin{tabular}{|c|c|c|c|c|c|}
\hline & Any source & $\begin{array}{l}\text { Employer own } \\
\text { coverage }\end{array}$ & $\begin{array}{l}\text { Employer } \\
\text { dependent } \\
\text { coverage }\end{array}$ & $\begin{array}{l}\text { Individually } \\
\text { purchased } \\
\text { coverage }\end{array}$ & $\begin{array}{l}\text { Government } \\
\text { provided }\end{array}$ \\
\hline \multirow{5}{*}{$\begin{array}{l}\text { High school or less } \\
\text { unemployment rate }\end{array}$} & $(\mathrm{N}=188,164)$ & $(\mathrm{N}=188,164)$ & $(\mathrm{N}=188,164)$ & $(\mathrm{N}=188,164)$ & $(\mathrm{N}=188,164)$ \\
\hline & $-0.0709 * * *$ & -0.0702 & 0.00853 & -0.0767 & 0.0372 \\
\hline & $(0.023)$ & $(0.020)$ & $(0.032)$ & $(0.040)$ & $(0.045)$ \\
\hline & {$[-0.0173]$} & {$[-0.0171]$} & {$[0.0014]$} & {$[-0.0134]$} & [0.0062] \\
\hline & $(0.006)$ & $(0.005)$ & $(0.006)$ & (0.009) & $(0.007)$ \\
\hline $\begin{array}{l}\text { mean of dependent } \\
\text { variables }\end{array}$ & 0.675 & 0.376 & 0.130 & 0.043 & 0.117 \\
\hline \multirow{5}{*}{$\begin{array}{l}\text { Some college } \\
\text { unemployment rate }\end{array}$} & $(\mathrm{N}=161,132)$ & $(\mathrm{N}=161,132)$ & $(\mathrm{N}=161,132)$ & $(\mathrm{N}=161,132)$ & $(\mathrm{N}=161,132)$ \\
\hline & $-0.0589 *$ & -0.0106 & 0.0211 & -0.0649 & -0.102 \\
\hline & $(0.035)$ & $(0.024)$ & $(0.039)$ & $(0.041)$ & $(0.067)$ \\
\hline & {$[-0.0137]$} & {$[-0.0011]$} & {$[0.0014]$} & {$[-0.0151]$} & {$[-0.0181]$} \\
\hline & $(0.008)$ & $(0.003)$ & $(0.006)$ & $(0.007)$ & $(0.012)$ \\
\hline $\begin{array}{l}\text { mean of dependent } \\
\text { variables }\end{array}$ & 0.809 & 0.525 & 0.166 & 0.059 & 0.049 \\
\hline \multirow{5}{*}{$\begin{array}{l}\text { Bachelor's degree or more } \\
\text { unemployment rate }\end{array}$} & $(\mathrm{N}=117,989)$ & $(\mathrm{N}=117,989)$ & $(\mathrm{N}=117,989)$ & $(\mathrm{N}=117,989)$ & $(\mathrm{N}=117,989)$ \\
\hline & $-0.106 \quad * *$ & -0.0596 & 0.0388 & -0.0306 & 0.0252 \\
\hline & $(0.041)$ & $(0.031)$ & $(0.042)$ & $(0.044)$ & $(0.122)$ \\
\hline & {$[-0.0214]$} & {$[-0.0138]$} & [0.0079] & {$[-0.0071]$} & {$[0.0038]$} \\
\hline & $(0.011)$ & $(0.008)$ & $(0.008)$ & $(0.008)$ & $(0.016)$ \\
\hline $\begin{array}{l}\text { mean of dependent } \\
\text { variables }\end{array}$ & 0.922 & 0.693 & 0.132 & 0.076 & 0.014 \\
\hline
\end{tabular}


Table 5 (continued): Probability of Health Insurance Coverage, by Education: Women Logit Regression (controlling for person- and year-specific fixed effects)

\begin{tabular}{|c|c|c|c|c|c|}
\hline & Any source & $\begin{array}{l}\text { Employer own } \\
\text { coverage }\end{array}$ & $\begin{array}{l}\text { Employer } \\
\text { dependent } \\
\text { coverage }\end{array}$ & $\begin{array}{l}\text { Individually } \\
\text { purchased } \\
\text { coverage }\end{array}$ & $\begin{array}{c}\text { Government } \\
\text { provided }\end{array}$ \\
\hline High school or less & $(\mathrm{N}=187,884)$ & $(\mathrm{N}=187,884)$ & $(\mathrm{N}=187,884)$ & $(\mathrm{N}=187,884)$ & $(\mathrm{N}=187,884)$ \\
\hline \multirow[t]{4}{*}{ unemployment rate } & -0.0034 & -0.0050 & 0.0053 & -0.0503 & -0.0033 \\
\hline & $(0.024)$ & $(0.021)$ & $(0.028)$ & $(0.052)$ & $(0.030)$ \\
\hline & {$[-0.0008]$} & {$[-0.0007]$} & {$[0.0013]$} & {$[-0.0035]$} & {$[-0.0007]$} \\
\hline & $(0.005)$ & $(0.003)$ & $(0.005)$ & $(0.007)$ & $(0.006)$ \\
\hline $\begin{array}{l}\text { mean of dependent } \\
\text { variables }\end{array}$ & 0.742 & 0.253 & 0.231 & 0.049 & 0.200 \\
\hline Some college & $(\mathrm{N}=190,050)$ & $(\mathrm{N}=190,050)$ & $(\mathrm{N}=190,050)$ & $(\mathrm{N}=190,050)$ & $(\mathrm{N}=190,050)$ \\
\hline \multirow[t]{4}{*}{ unemployment rate } & -0.0261 & 0.0078 & -0.0166 & -0.0209 & -0.0202 \\
\hline & $(0.024)$ & $(0.026)$ & $(0.030)$ & $(0.038)$ & $(0.041)$ \\
\hline & {$[-0.0059]$} & {$[0.0017]$} & {$[-0.0038]$} & {$[-0.0038]$} & {$[-0.0043]$} \\
\hline & $(0.005)$ & $(0.005)$ & $(0.006)$ & $(0.007)$ & $(0.008)$ \\
\hline $\begin{array}{l}\text { mean of dependent } \\
\text { variables }\end{array}$ & 0.844 & 0.371 & 0.302 & 0.063 & 0.094 \\
\hline \multirow{5}{*}{$\begin{array}{l}\text { Bachelor's degree or more } \\
\text { unemployment rate }\end{array}$} & $(\mathrm{N}=132,400)$ & $(\mathrm{N}=132,400)$ & $(\mathrm{N}=132,400)$ & $(\mathrm{N}=132,400)$ & $(\mathrm{N}=132,400)$ \\
\hline & -0.0776 & -0.0053 & $-0.0662 *$ & 0.0204 & 0.0524 \\
\hline & $(0.051)$ & $(0.030)$ & $(0.033)$ & $(0.036)$ & $(0.076)$ \\
\hline & {$[-0.0190]$} & {$[-0.0009]$} & {$[-0.0163]$} & {$[0.0044]$} & {$[0.0131]$} \\
\hline & $(0.012)$ & $(0.004)$ & $(0.008)$ & $(0.009)$ & $(0.010)$ \\
\hline $\begin{array}{l}\text { mean of dependent } \\
\text { variables }\end{array}$ & 0.937 & 0.530 & 0.302 & 0.073 & 0.020 \\
\hline
\end{tabular}

Notes: (1) See Notes (1)-(5) under Table 2.

(2) Other regressors are individual fixed effects, year-specific fixed effects, age, marital status, and presence of children in the family. 
Table 6: Probability of Health Insurance Coverage, by Race Logit Regression (controlling for person- and year-specific fixed effects)

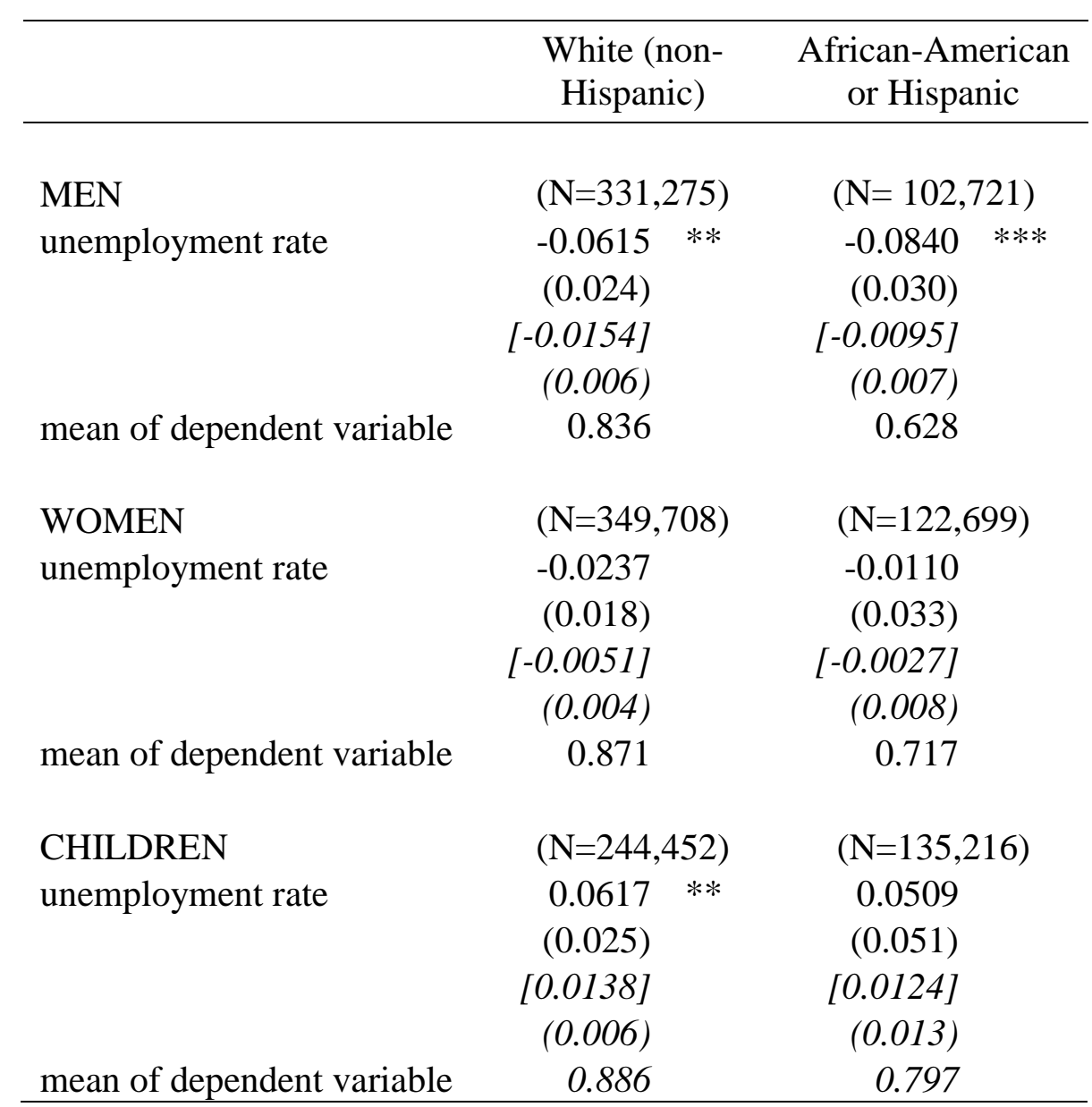

Notes: (1) See Notes (1)-(4) under Table 2.

(2) A dependent variable in each column is an indicator variable that equals 1 if individual covered by health insurance from any source and 0 otherwise.

(3) Other regressors are individual fixed effects, year-specific fixed effects, age, highest grade completed, marital status, and presence of children in the family (The last three variables are not included in the regressions for children.). 
Table 7: Probability of Health Insurance Coverage, by Age Logit Regression (controlling for person- and year-specific fixed effects)

\begin{tabular}{lccc}
\hline & & & \\
& $18-34$ years & $35-49$ years & $50-64$ years \\
& & & \\
MEN & & & \\
unemployment rate & $\mathrm{N}=165,372)$ & $(\mathrm{N}=163,411)$ & $(\mathrm{N}=138,502)$ \\
& $-0.0574 * *$ & $-0.0683 * *$ & $-0.105 \quad * * *$ \\
& $(0.027)$ & $(0.032)$ & $(0.039)$ \\
mean of dependent variable & {$[-0.0134]$} & {$[-0.0156]$} & {$[-0.0250]$} \\
& $(0.006)$ & $(0.007)$ & $(0.010)$ \\
WOMEN & 0.693 & 0.810 & 0.870 \\
unemployment rate & $(\mathrm{N}=175,088)$ & $(\mathrm{N}=178,729)$ & $(\mathrm{N}=156,517)$ \\
& -0.0076 & -0.0277 & -0.0526 \\
& $(0.020)$ & $(0.027)$ & $(0.044)$ \\
mean of dependent variable & $0.0019]$ & {$[-0.0069]$} & {$[-0.0112]$} \\
& $(0.005)$ & $(0.006)$ & $(0.008)$ \\
& 0.775 & 0.842 & 0.879 \\
\hline
\end{tabular}

Notes: (1) See Notes (1)-(4) under Table 2.

(2) A dependent variable in each column is an indicator variable that equals 1 if individual covered by health insurance from any source and 0 otherwise.

(3) Other regressors are individual fixed effects, year-specific fixed effects, highest grade completed, marital status, and presence of children in the family (The last three variables are not included in the regressions for children.). 